Vol. 10 No. 2, Desember 2018

\title{
Pengaruh Terapi Murottal Terhadap Tingkat Kecemasan Pada Ibu Bersalin Normal di Polindes Permata Bunda Kelurahan Perbon Kecamatan Tuban Kabupaten Tuban
}

\author{
Umu Qonitun ${ }^{1}$, Betalia ${ }^{2}$ \\ ${ }^{1}$ Program Studi D III Kebidanan STIKES Nahdlatul Ulama Tuban \\ 2 Program Studi D III Kebidanan STIKES Nahdlatul Ulama Tuban \\ Email : hafizh.hak@gmail.com
}

\begin{abstract}
ABSTRAK
Kecemasan merupakan kondisi kejiwaan yang penuh dengan kekhawatiran akan apa yang mungkin terjadi. Seorang calon ibu sering kali dilanda kecemasan menghadapi masa persalinan. Kecemasan menimbulkan dampak secara fisik maupun psikis pada janin, ibu dan proses persalinan yang dijalaninantinya. Terapi murottal bisa memberikan solusi kapada ibu yang mengalami kecemasan pada saat proses persalinan. Tujuan penelitian ini untuk mengetahui pengaruh terapi murottal terhadap tingkat kecemasan pada ibu bersalin normal di polindes Permata Bunda kelurahan Perbon kecamatan Tuban kabupaten Tuban.

Desain penelitian ini adalah Pre eksperimen dengan rancangan yang digunakan One group prepost test.Dengan besar sampel penelitian 19 responden.Variabel independen dalam penelitian ini adalah terapi murottal, sedangkan variable dependen adalah tingkat kecemasan. Teknik pengambilan sampel menggunakan systematic random sampling, dan instrument pengumpulan data menggunakan observasi yang selanjutnya dianalisis menggunakan uji wilcoxon dengan nilai $(\alpha=0,001)$.

Berdasarkan hasil uji statistika menunjukan variable terapi murottal ada pengaruh signifikan dengan tingkat kecemasan dengan $p$ value $=(<0,05)$. Dari uraian diatas dapat disimpulkan bahwa untuk mencegah terjadinya kecemasan pada ibu menghadapi persalinan maka dapatdiberikan dukunganspiritual yaitu dengan memberikan terapi murottal serta ketrampilan dari tenaga medis sangat mempengaruhi kondisi psikologi sibu untuk menjalani proses persalinan.
\end{abstract}

\section{Kata Kunci: Terapi murottal, tingkat kecemasan.}

\begin{abstract}
Anxiety is a psychiatric state full of worries about what might happen. a prospective mother is often hit by anxiety facing labor. Anxiety impacts physically and psychologically on the fetus, mother and delivery process that will be lived later. Murottal therapy can be given solution for mother who experience anxiety at the time of childbirth. The purpose of this study to determine the influence of murottal therapy on anxiety levels in normal maternal mothers in Polindes Permata Bunda Perbon Tuban.

The design of this study is pre experimentin use One Group pre-post test . with a large sample of 19 respondents. Independent variable in this study is murottal therapy, while the dependent variable is anxiety levels. Sampling technique using systematic random sampling, and instrument of data collection using observationwhich then analyzed using Wilcoxon sign rank test with value $(\alpha=$ $0,001)$.

Based on the results of statistical tests showed the variable murottal therapysignificantly related to the anxiety levelswith $p$ value $=(<0,05)$. From the description above can be concluded that to prevent anxiety on maternal mother it can be given spiritual support with giving murottal therapy and skills from medical personnel greatly affect the psychological condition of the mother to undergo the process of childbirth
\end{abstract}

Keywords: Murottal therapy, anxiety levels 


\section{PENDAHULUAN}

Pada wanita hamil dan bersalin merupakan masalah besar di negara berkembang. Masa persalinan merupakan periode kritis bagi seorang calon ibu. Ibu hamil pertama tidak jarang memiliki pikiran yang mengganggu, Adanya kecemasan serta pikiran-pikiran seperti melahirkan yang akan selalu di ikuti dengan nyeri. Kecemasan pada ibu bersalin adalah reaksi emosional pasien yang sering muncul, hal ini merupakan respon antisipasi terhadap suatu pengalaman yang dapat di anggap pasien sebagai ancaman perannya dalam hidup, integritas tubuh atau bahkan kehidupannya itu sendiri. (Bareadero, 2008). Di indonesia, sekitar $95 \%$ tenaga kesehatan tidak terlalu memperhatikan kondisi psikis wanita melahirkan. Akan tetapi lebih memperhatikan kondisi fisik ibu dan bayi yang di lahirkannya. Banyak wanita yang memilih persalinan dengan oprasi atas dasar pertimbangan tertentu. Terutama ibu membayangkan rasa sakit pada proses persalinan (Suryani, 2011). Di Indonesia terdapat 373.000 ibu hamil, yang mengalami kecemasan dalam menghadapi persalinan ada sebanyak 107.000 orang $(28,7 \%)$. Seluruh populasi di pulau jawa terdapat 67.979 ibu hamil, sedangkan yang mengalami kecemasan dalam menghadapi persalinan 35.587 orang (52,3 \%) (Depkes RI, 2008). Berdasarkan survey pendahuluan yang di lakukan pada tanggal 8 desember 2017 di polindes Permata Bunda kelurahan Perbon kecamatan Tuban kabupaten Tuban di dapatkan 3 dari 5 ibu bersalin mengalami kecemasan. Sehingga 2 dari 3 ibu yang mengalami kecemasan mengakibatkan terjadinya partus lama. kemudian 2 dari 5 ibu bersalin yang mengalami partus lama, 1 diantaranya harus di rujuk ke rumah sakit.

Selama kehamilan, ibu mengalami perubahan fisik dan psikis yang terjadi akibat perubahan hormon. Perubahan ini akan mempermudah janin untuk tumbuh dan berkembang sampai saat di lahirkan (Kushartanti, dkk, 2004). Adapun pada trimester ke tiga (27-40 minggu) kecemasan menjelang persalinan ibu hamil pertama akan muncul. Pertanyaan dan bayangan apakah dapat melahirkan normal, cara mengejan, apakah akan terjadi sesuatu saat melahirkan atau apakah bayi lahir selamat, akan semakin sering muncul dalam benak ibu hamil. Hal senada juga di ungkap Kartono (2008) dan Kalil, dkk, (2011) bahwa pada usia 7 bulan ke atas tingkat kecemasan ibu hamil semakin akut dan intensif seiring dengan mendekatnya kelahiran bayi pertamanya. Di samping itu, trimester ini merupakan masa riskan terjadinya kelahiran bayi prematur sehingga menyebabkan tingginya keceemasan pada ibu hamil (Sridadi, dalam Daryo,2012).

Beberapa upaya telah dilakukan untuk menangani kecemasan pada ibu bersalin seperti pemberian aroma terapi, dukungan spiritual, dan relaksasi progresif. Salah satu cara untuk mengatasi kecemasan yaitu terapi suara atau terapi musik yang berguna dalam proses persalinan karena dapat menurunkan rasa nyeri dan dapat membuat perasaan klien rileks (Qonitun, 2016). Terapi musik telah banyak diterapkan sebagai alternatif untuk mempercepat penyembuhan, namun belum banyak yang melakukan penelitian tentang terapi membaca Al-Qur'an (terapimurottal) untuk membantu proses kelancaran persalinan. Terapi pembacaan Al-Qur'an (terapimurottal) yang diperdengarkan di rumah sakit ternyata bias membangkitkan tanggapan relaksasi atau penurunan ketegangan urat saraf reflek (Al-Qadhi, 2009).

\section{BAHAN DAN METODE}

Penelitian ini termasuk jenis penelitian One-group pra-post test design. Jenis sampling dalam penelitian ini menggunakan simple random sampling. variabel independen dalam penelitian ini adalah terapi murottal sedangkan variabel dependen adalah tingkat kecemasan proses persalinan. 
Vol. 10 No. 2, Desember 2018

Sampel dalam penelitian ini yang masuk kriteria inklusi eksklusi sebanyak 19 responden. Penelitian ini dilakukan selama 2 bulan dengan. Pelaksanaan pemberian terapi murottal dengan melalui earphone selama 15 menit.

Instrumen yang digunakan dalam penelitian ini adalah lembar observasi dengan menggunakan anxietas NANDA International Scale. observasi terdiri dari 18 pernyataan dengan rentang skor antara <21-36 dengan nilai skor akhir = skor perolehan dibagi skor maksimal dikali $100 \%$ yang artinya apabila ibu bersalin mendapat skor $100 \%$ berarti seluruhnya ibu mengalami kecemasan, $76 \%$ - 99\% hampir seluruhnya, $51 \%$ - $75 \%$ sebagian besar, $50 \%$ berarti setengahnya, 26\% $49 \%$ hampir setengahnya, $1 \%-25 \%$ sebagian kecil, $0 \%$ berarti tidak satupun mengalami kecemasan.

Dua bulan setelah pelaksanaan kegiatan dilakukan post-test dengan menggunakan observasi anxietas NANDA International Scale.

\section{HASIL PENELITIAN}

Tabel 5.1 Distribusi Responden Berdasarkan Umur pada Ibu Bersalin Normal di Polindes Permata Bunda Kelurahan Perbon Kecamatan Tuban Kabupaten Tuban Tahun 2018

\begin{tabular}{cccc}
\hline No & Umur & Frekuensi & Presentase $(\%)$ \\
\hline 1. & $<21$ & 2 & 10,5 \\
2. & $21-30$ & 13 & 68,5 \\
3. & $>30$ & 4 & 21 \\
\hline & Jumlah & 19 & 100 \\
\hline
\end{tabular}

Dari tabel 5.1 di atas dapat diketahui bahwa sebagian besar 13 $(68,5 \%)$ responden berumur 21-30, dan sebagian kecil $2(10,5 \%)$ responden berumur kurang dari 20.

Tabel 5.2 Distribusi Responden Berdasarkan Pekerjaan pada Ibu Bersalin Normal di Polindes Permata Bunda Kelurahan Perbon Kecamatan Tuban Kabupaten Tuban Tahun 2018

\begin{tabular}{cccc}
\hline No & Pekerjaan & Frekuensi & $\begin{array}{c}\text { Presentase } \\
(\%)\end{array}$ \\
\hline 1 & Swasta & 3 & 15,8 \\
2 & $\begin{array}{c}\text { Tidak } \\
\text { bekerja }\end{array}$ & 16 & 84,2 \\
& Jumlah & 19 & 100 \\
\hline
\end{tabular}

Sumber: Data Primer, Tahun 2018

Berdasarkan tabel 5.2 diatas dapat diketahui bahwa sebagian besar 16 $(84,2 \%)$ responden tidak bekerja. Dan sebagian kecil $3(15,8 \%)$ responden bekerja sebagai swasta.

Tabel 5.3 Distribusi Responden Berdasarkan Pendidikan pada Ibu Bersalin Normal di Polindes Permata Bunda Kelurahan Perbon Kecamatan Tuban Kabupaten Tuban Tahun 2018

\begin{tabular}{|c|c|c|c|}
\hline No & Pendidikan & Frekuensi & $\begin{array}{c}\text { Presentase } \\
(\%)\end{array}$ \\
\hline 1 & Sarjana S1 & 3 & 15,8 \\
\hline 2 & SMA & 16 & 84,2 \\
\hline & Jumlah & 19 & 100 \\
\hline
\end{tabular}

Berdasarkan tabel 5.3 diatas dapat diketahui bahwa sebagian besar 16 $(84,2 \%)$ responden berpendidikan SMA. Dan sebagian kecil $3(15,8 \%)$ responden berpendidikan sarjana $\mathrm{S} 1$.

Tabel 5.4 Distribusi Responden Berdasarkan Paritas pada Ibu Bersalin Normal di Polindes Permata Bunda Kelurahan Perbon Kecamatan Tuban Kabupaten Tuban Tahun 2018

\begin{tabular}{cccc}
\hline No & Paritas & Frekuensi & Presentase $(\%)$ \\
\hline 1. & 1 & 12 & 63,2 \\
2. & 2 & 5 & 26,3 \\
3. & 3 & 2 & 10,5 \\
\hline & Jumlah & 19 & 100 \\
\hline
\end{tabular}

Sumber: Data Primer, Tahun 2018

Dari tabel 5.4 di atas dapat diketahui bahwa sebagian besar 12 $(63,2 \%)$ responden berparitas 1 , dan sebagian kecil $2(10,5 \%)$ responden berparitas 3 .

Tabel 5.5 Distribusi Frekuensi Kecemasan Pada Ibu Bersalin 
Vol. 10 No. 2, Desember 2018

Normal Sebelum Diberikan Terapi Murottal Di Polindas Permata Bunda Kecamatan Tuban Kabupaten Tahun 2018

\begin{tabular}{clcc}
\hline No & \multicolumn{1}{c}{$\begin{array}{c}\text { Tingkat } \\
\text { Kecemasan }\end{array}$} & Frekuensi & $\begin{array}{c}\text { Persentase } \\
(\%)\end{array}$ \\
\hline 1. & $\begin{array}{l}\text { Kecamasan } \\
\text { ringan }\end{array}$ & 3 & 15,8 \\
2. & $\begin{array}{l}\text { Kecemasan } \\
\text { sedang }\end{array}$ & 6 & 31,6 \\
3. & $\begin{array}{l}\text { Kecemasan } \\
\text { berat }\end{array}$ & 10 & 52,6 \\
\hline & Jumlah & 19 & 100 \\
\hline & Sumber: Data Primer, Tahun 2018
\end{tabular}

Berdasarkan tabel 5.5 di atas dapat diketahui bahwa dari 19 responden sebelum di berikan Terapi Murottal sebagian besar sebanyak $10 \quad(52,6 \%)$ responden mengalami kecemasan berat, dan sebagian kecil sebanyak 3 (15,8\%) responden mengalami kecemasan ringan.

Tabel 5.6 Distribusi Frekuensi

Kecemasan Pada Ibu Bersalin

Normal Sesudah Diberikan

Terapi Murottal Di Polindas

Permata Bunda Kecamatan

Tuban Kabupaten Tahun 2018

\begin{tabular}{|c|c|c|c|}
\hline No & $\begin{array}{c}\text { Tingkat } \\
\text { Kecemasan }\end{array}$ & Frekuensi & $\begin{array}{c}\text { Persentase } \\
(\%)\end{array}$ \\
\hline 1. & $\begin{array}{l}\text { Kecemasan } \\
\text { ringan }\end{array}$ & 10 & 52,6 \\
\hline 2. & $\begin{array}{l}\text { Kecemasan } \\
\text { sedang }\end{array}$ & 5 & 26,3 \\
\hline 3. & $\begin{array}{l}\text { Kecemasan } \\
\text { berat }\end{array}$ & 4 & 21,1 \\
\hline & Jumlah & 19 & 100 \\
\hline
\end{tabular}

Sumber: Data Primer, Tahun 2018

Berdasarkan tabel $5.6 \mathrm{di}$ atas dapat diketahui bahwa dari 19 responden setelah di berikan Terapi murottal sebagian besar sebanyak $10 \quad(52,6 \%)$ responden mengalami kecemasan ringan.

Tabel 5.7 Analisis Pengaruh Terapi Murottal Terhadap Tingkat Kecemasan Pada Ibu Bersalin Normal Di Polindes Permata Bunda Kelurahan Perbon Kecamatan Tuban Kabupaten Tuban Tahun 2018

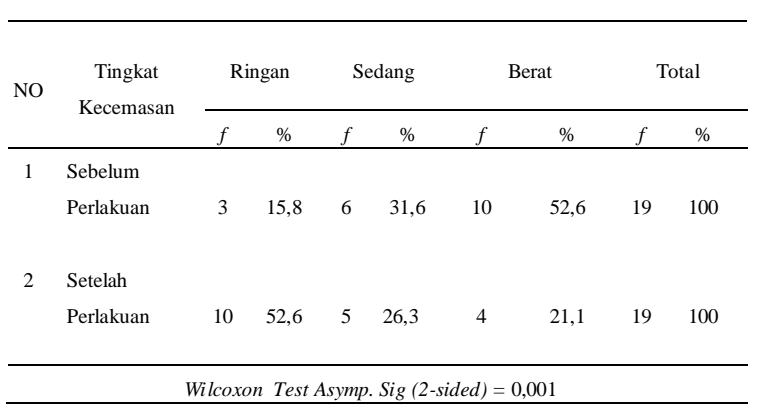

Tabel 5.7 di atas menunjukkan bahwa sebelum diberikan perlakuan, responden yang memiliki kecemasan ringan yaitu sebanyak $3(15,8 \%)$ dan setelah diberikan perlakuan responden yang memiliki kecemasan ringan sebanyak $10(52,6 \%)$.

Dari table 5.6 menunjukkan bahwa ada pengaruh terapi murottal terhadap tingkat kecemasan pada ibu bersalin normal di Polindes Permata Bunda Perbon Tuban. Ditunjukkan dengan (52,6 \%) responden memiliki kecemasan paling berat sebelum di berikan terapi murottal dan $(52,6 \%)$ responden memiliki kecemasan ringan sesudah diberikan terapi murottal.

Selanjutnya ditabulasi kedalam tabel yang kemudian dianalisis dengan uji Wilcoxon dengan derajat kemaknaan $\alpha=0,05$. Hasil uji statistik menggunakan Wilcoxon diperoleh Asymp. Sig. (2-tailed) $\mathrm{p}$ value $=0,001$, dimana $0,001<0,05$, maka $\mathrm{H}_{1}$ diterima sehingga disimpulkan bahwa terdapat pengaruh terapi murottal terhadap tingkat kecemasan pada ibu bersalin normaal di Polindes Permata Bunda Perbon Tuban

\section{PEMBAHASAN}

\section{Tingkat Kecemasan Pada Ibu Bersalin Normal Sebelum Di Berikan Terapi Murottal}

didapatkan hasil bahwa sebelum diberikan terapi murottal surah Al-fatihah dari 19 responden ibu hamil menunjukan bahwa sebagian besar responden mengalami kecemasan berat dan sebagian kecil mengalami kecemasan ringan.

Kecemasan ini merupakan respon psikologis yang lazim ditemukan pada ibu 
yang akan menjalani persalinan. Beberapa ibu kadang tidak mampu mengontrol kecemasan yang dihadapi, sehingga terjadi disharmoni dalam tubuh. Hal ini akan berakibat buruk, karena apabila tidak segera diatasia kan meningkatkan tekanan darah dan pernafasan yang dapat menyebabkan pendarahan baik pada saat persalinan ataupun pasca persalinan (Effendy, 2009).

Tingginya tingkat kecemasan ini dipengaruhi oleh beberapa faktor diantaranya adalah tingkat pendidikan, umur,pekerjaan dan jenis persalinan. Responden dalam penelitian ini sebagian besar berpendidikan SMA, hal ini membenarkan teori yang dikemukakan oleh (Stuart, 2006) bahwa tingkat pendidikan yang rendah akan menyebabkan orang tersebut mudah mengalami kecemasan. Tingkat pendidikan seseorang atau individu akan berpengaruh terhadap kemampuan berfikir, semakin tinggi tingkat pendidikan akan semakin mudah berfikir rasional dan menangkap informasi baru termasuk dalam menguraikan masalah yang baru. Tingkat pendidikan responden yang rendah kurang menunjang kemampuan untuk memahami kondisidirinya, sehingga kurang pula pemahaman tentang kelemahan dan kelebihan dirinya. Pemahaman tentang sisi kelemahan dan kelebihan yang baik menimbulkan mekanisme koping yang baik pula pada diri responden untuk menghadapi pengalaman yang baru. ( Efendy, 2009)

Fakto rlain yang mempengaruhi tingkat kecemasan adalah umur, responden dalam penelitian ini sebagian besar berusia dewasa awal. Umur yang lebih muda akan mengalami tingkat stress dan kecemasan lebih tinggi dari pada yang berusia tua. Hal ini di karenakan usia berhubungan dengan pengalaman dan pandangan terhadap sesuatu, semakin bertambah usia seseorang maka semakin matang proses berfikir dan bertindak dalam menghadapi sesuatu. Kematangan dalam proses berfikir pada individu yang berumur dewasa lebih memungkinkan untuk menggunakan mekanisme koping yang baik di bandingkan umur yang lebih muda ( Stuart, 2006)

Pekerjaan juga sebagai salah satu faktor yang mempengaruhi kecemasan seseorang, Hal ini membenarkan teori yang dikemukakan oleh (Tarwoto danWartonah, 2008) responden dalam penelitian ini sebagian besar tidak memiliki pekerjaan. Bahwa seseorang yang tidak mempunyai pekerjaan dan tidak memerlukan aktifitas maka akan menimbulkan perubahan status atau peran kegiatan tersebut, hal ini penyebab timbulnya kecemasan dan akan mempengaruhi perannya dimasyarakat. Responden penelitian ini semuanya perempuan dan sebagian besar tidak bekerja. Ibu rumah tangga merupakan tugas yang menguras kemampuan fisik maupun mental. Seorang ibu rumah tangga mempunyai tanggung jawab yang besar, yaitu mengurus semua keluarga untuk kebutuhan sehari-hari maupun untuk kebutuhan anak dan suami dirumah. Ibu yang akan menjalani persalinan akan berdampak pada keadaan mental responden dan hal ini juga merupakan factor pemicu terjadinya kecemasan responden saat akan menjalani persalinan.

Jenis persalinan juga berpengaruh terhadaptingginya tingkat kecemasan responden. Dalam penelitian ini, semua responden menjalani persalinan normal. Hal ini membenarkan teori yang dikemukakan oleh (Baradero, 2008) bahwa sekalipun persalinan tersebut dianggap minor oleh tenaga kesehatan profesional, tetapi persalinanpun selalu dianggap sebagai sesuatu yang besar oleh pasien dan keluarganya. Besar kecilnya jenis persalinan sangat berpengaruh terhadap tingkat kecemasan yang dialami oleh ibu bersalin, ini dikarenakan juga dalam penelitian ini responden baru pertama kali menjalani persalinan sehingga pasien merasa adanya ketakutan yang berlebih, taku tbayi tidak lahir secara normal, takut terjadi kecacatan pada bayi, takut terjadi 
perdarahan pada ibu,dan takut terjadi kematian pada bayi.

Hasil penelitian ini terdapat 10 responden yang mengalami kecemasan berat, hal ini ditandai dengan adanya rasa takut yang di tunjukkan melalui respon mimik muka pasien dan adanya rasa kesakitan atau nyeri pada pasien. Dalam penelitian ini menyampaikan bahwa persalinan dapat dipandang secara umum sebagai satu bentuk krisis dan timbulnya perasaan kecemasan dan ketakutan. Apabila ibu menjalani persalinan dapat dipastikan ibu tersebut mengalami kecemasan, setiap orang berbeda pandangan dalam menghadapi persalinan sehingga responnya berbeda-beda, namun sesungguhnya selalu terjadi ketakutan pada pasien yang menjalani persalinan. Oleh karena itu, proses persalinan memerlukan suatu penanganan spesifik yang melibatkan semua aspek bio-psikososial dan spiritual.

Identifikasi Tingkat Kecemasan Pada Ibu Bersalin Normal Sesudah Di Berikan Terapi Murottal

Peneliti dalam mengatasi kecemasan pada ibu bersalin, memberikan tindakan berupa terapi murottal selama 15 menit, dengan harapan ibu bersalin dapat menghadapi proses persalinan dengan tenang sehingga tidak mempengaruhi kelancaran proses persalinan. Pada responden dilakukan pengukuran tingkat kecemasannya denga nmenggunakan anxiety NANDA International Scale untuk mengetahui adakah pengaruh murottal yang telah diberikan.

Hasil pengukuran setelah diperdengarkan terapi murottal didapatkan hasil seperti pada tabel 5.6 sebagian besa ribu bersalin mengalami kecemasan ringan dan sebagian kecil ibu bersalin mengalami kecemasan berat. Hal ini menunjukan bahwa terjadi penurunan tingkat kecemasan pada responden setelah diperdengarkan terapi murottal.

$$
\text { Adanya penurunan tingkat }
$$

kecemasan disebabkan oleh faktor murottal secara langsung memberikan pengaruh fisik dan psikis terhadap responden. Hal ini ditandai dengan sebagian responden mengatakan merasa lebih tenang saat diperdengarkan terapi murottal dan pernafasan mereka teratur. Menurut pengamatan peneliti hal ini terjadi akibat responden meresapi dan benar-benar melakukan serangkaian intervensi dengan baik.

Dalam penelitian Harianto, 2012 yang dikutip dalam Heru, 2008 menyampaikan bahwa distraksi yang diperoleh dari efek yang didapatkan dari terapi murottal memberikan individu control diri ketika terjadi rasa tidak nyaman, stress fisik, dan emosi yang bertujuan untuk mengurangi ketegangan dan kecemasan. Respon fisiologis dengan teknik distraksi ini juga dapat menurunkan tekanan darah serta memperlambat pernafasan, detak jantung, dan denyut nadi sehingga menggunakan terapi murottal ini sebagai media salah satu untuk mengurangi kecemasan pada persalinan.

Selain factor diatas, kecemasan pada persalinan dapat diturunkan melalui banyak metode yang dapat dilakukan perawat. Beberapa metode yang pernah dilakukan dalam mengurangi tingkat kecemasan pada persalinan yaitu aroma terapi, keperawatan spiritual dan terapi musik. Dalam wawancara yang dilakukan pada responden sesudah diberikan terapi murottal sebagian besar responden mengatakan menikmati dan menyukai terapi yang diberikan karena belum pernah mendapatkan terapi ini sebelumnya.

\section{Pengaruh Terapi Murottal Terhadap Tingkat Kecemasan Pada Ibu Bersalin Normal}

Data yang didapatkan oleh peneliti dari 19 responden dapat diketahui bahwa sebelum diberikan perlakuan sebagian besar responden mengalami kecemasan berat dan setelah diberikan perlakuan sebagian besar responden mengalami kecemasan ringan. Data yang diperoleh oleh peneliti bahwa hamper seluruhnya responden kecemasannya berkurang sesudah diberikan perlakuan, dan sebagian 
kecil responden kecemasannya tetap sesudah diberikan perlakuan.

Terjadinya perubahan tingkat kecemasan pada responden, disamping dipengaruhi oleh umur, tingkat pendidikan, pekerjaan, jenis persalinan juga dipengaruhi oleh kultur, perkembangan, pengalaman hidup, dan ide-ide sendiri tentang hidup. Pada saat seseorang mengalami stres, penyakit, penyembuhan, kehilangan mekanisme koping yang digunakan adalah keyakinan atau nilai dasar hidup orang tersebut dan keyakinan ini berakar dalam spiritual (Potter \& Perry, 2010).

Hasil analisa data yang digunakan pada penelitian ini adalah uji Wilcoxon. Hasil uji statistik menggunakan Wilcoxon menunjukkan bahwa ada pengaruh terapi murottal terhadap tingkat kecemasan padaa ibu bersalin normal di Polindes Permata Bunda Perbon Tuban.

\section{SIMPULAN DAN SARAN}

Hasil penelitian ini menunjukkan ada pengaruh terapi murottal terhadap tingkat kecemasan pada ibu bersalin normal di Polindes Permata Bunda Perbon Tuban. Ditunjukkan dengan hasil analisa data yang digunakan pada penelitian ini adalah uji Wilcoxon dengan derajat kemaknaan 0,05 . Hasil uji statistik menggunakan Wilcoxon diperoleh $\mathrm{p}$ value $=0,001(\mathrm{p}$ value $<0,05)$.

\section{DAFTAR PUSTAKA}

Fithroh Roshinah, Laila Nursaliha, dan Saiful Amri. 2014. Efektifitas Pemberian Terapi Murottal Terhadap Penurunan Tingkat Kecemasan Pada Pasien Pre Oprasi Fraktur di Ruang Kemuning Rumah Sakit Umum Provinsi NTB, (http://www.repository.unand.ac.i d) diakses 10 November 2017

Maelina Ariyanti, Heri Bachtiar, Melati Inayati Albayani. 2015. Pengaruh Terapi Murottal Terhadap Tingkat Hiperaktif - Impulsif
Pada Anak Attention Hyperactive Disorder (ADHD), (http://www.jurnal.urutan.ac.id) diakses 10 November 2017c.id

Yurike Septianingrum, 2014. Efektifitas Senam Hamil Sebagai Pelayanan

Prenatal dalam Menurunkan Kecemasan Menghadapi Persalinan Pertama, (http://www.jki.ui.ac.id diakses 10 November 2017

Primatia Yogi Wulandari, efektifitas Senam Hamil Sebagai Pelayanan Prenatal dalam Menurunkan Kecemasan Menghadapi Persalinan. 2014, (http://www.publikasiilmiah.ums. ac.id)diakses 11 November 2017

Stuart \& Sundeen. 1998. Buku Saku Keperawatan Jiwa . Edisi 3.EGC

Stuart, Gail W. 2006. Buku Saku Keperawatan Jiwa. Jakarta

Nursalam. 2013. Konsep Dan Penerapan Metodologi Penelitian Ilmu Keperawatan. Jakarta: Salemba Medika.

Nursalam, 2016. Metode Penelitian Ilmu Keperawatan Edisi 4. Jakata:Salemba Medika

Harianto, Mohammad David. 2012. Pengaruh Pemberian Terapi Murottal Terhadap Pengurangan Tingkat Nyeri Pasien Pasca Oprasi Persalinan Di RSNU Tuban. Skripsi tidak diterbitkan. Tuban: STIKES NU Tuban Prodi S1 Keperawatan.

Rita wati, 2016. Pengaruh Terapi Murottal Surah Al-Fatihah Terhadap Tingkat Kecemasan Pada Pasien Pre Operasi di RSUD Dr, Koesma Tuban. Skripsi tidak di terbitkan. Tuban: STIKES NU Tuban Prodi S1 Keperawatan.

Mohammad Ma'ruf Syarifuddin, 2016. Hubungan Antara Usia Dengan Tingkat Kecemasan Menghadapi Proses Persalinan Pada Ibu Bersalin Pada Ibu Primigravida 
Vol. 10 No. 2, Desember 2018

Trimester 3. Skripsi tidak di terbitkan. Tuban: STIKES NU Tuban Prodi S1 Keperawatan.

Siwi Walyani Elisabeth Amd. Keb, Purwoastuti Endang, S. Pd, APP, 2016. Asuhan Kebidanan Persalinan \& Bayi Baru Lahir. PT: Pustaka Baru Press

Depkes, 2015. Dinas Kesehatan Provinsi Jawa Timur (http//www.Depkes.go.id) 15 jatim_15. Diakses 19 November 2017

Rusfita Retna, 2017. Pengaruh Murottal Al-Qur'an Terhadap Penurunan Nyeri Persalinan di Puskesmas Wilayah

Banjarnegara.(http//www.digilib. unisayoga.ac.id) diakses 21 November

Qonitun, 2016. Pengaruh Teknik Relaksasi Pernapasan terhadap Intensitas Nyeri Persalinan Kala I di BPM Asri Tuban. Jurnal Sain Med, 36. https://scholar.google.co.id/citations? user=rlybxdAAAAAJ\&hl=id

Depkes, 2015. Angka Kematian Ibu Melahirkan (AKI).(http//www.Depkes.go.id). diakses 18 November 2017 